C. A. Hochwalt, Monsanto research and technology vicepresident (since retired), who studied the Russian reports. He formed the opinion that some phases of the Russian experiments were of technical interest and were worth following up by Monsanto scientists. It was Dr. M. M. Baizer of the Central Research Department who was critically concerned with one aspect of the Russian approach to the problem, that involving olectrolytic reactions; Dr. Baizer disagreed with widely accepted interpretations of the effect of an electric current on organic chemicals, in particular the alleged existence and functions of intermediate fragments, the 'free radicles'; he was convinced that these had been overrated, and were probably not involved at all in the main problem. Dr. Baizer accordingly set to work, on comparatively modest laboratory equipment centring on an electrolytic cell, to see whether his ideas were correct or otherwise. "In a fow months, he was ready to report that it did appear, indeed, that free radicles did not necessarily figure in the results. In addition, he was able to report a breakthrough into a now field of electro-organic chemistry. It was the direct electrolytic hydrodimerization of a broad variety of petrochemicals into others twice their molecular size." Later, his process was the basis for many patents, in one case ten being issued on the same day. The mechanism of the process involved is shown diagrammatically in colour in the article and may, in summary, be conveyed as follows: the sequence begins as two acrylonitrile molecules in an electrolyte-water solution are drawn together when current from a cathode breaks the carbon double bond in the first, 'charging' it, causing the carbon double bond in the second to break as the two molecules join ('carbanion'); at this stage two hydrogen atoms from the water are attracted, thus the adiponitrile molecule is formed. Within two years of this discovery, a multimillion-dollar Monsanto plant, with batteries of electrolytic cells many times larger than the original cell used by Dr. Baizer, is busily and efficiontly converting acrylonitrile into adiponitrile at Decatur, Alabama; this was described as a technological feat for which, in 1965 , Monsanto won one of the most prized honours in this ficld in America, the Kirkpatrick Award for Chemical Engineering Achievement.

\section{Morphological Analysis by Digital Computer}

A COMPUTER-ORIENTED approach to the analysis of microscopic images has been developed by M. L. Mendelsoln, W. A. Kolman, B. Pery and J. M. S. Prewitt, of the Department of Radiology, University of Pennsylvania, around $C Y D A C$, a data conversion system which scans through the microscope and records the optical information in digital form on magnetic tape (Methodik der Information in der Medizin, 4, No. 4; December 1965). The quality of the optical information thus made available to the computer is surprisingly good, as shown by the reconstruction of the original image using the high speed printer. Preparations for the computer interpretation of scanned images are under way, using blood cells as a model system. Parallel attempts to classify human chromosomes by means of $C Y D A C$ seans have given encouraging preliminary results.

\section{Developments in Pure Chemicals}

As present the research and development programme of the B.D.H. Laboratory Chemicals Division is aimed mainly at the production of highly purified inorganic compounds used for optical purposes-prineipally the hot-pressing of infra-red windows and the growing of crystals for a variety of purposes. The emphasis is always on greater and greater purity since optical properties are profoundly influenced by small traces of some impurities. Associated with this programme is the preparation of highly pure acids and solvents; these are used primarily by the electronics industry for the etching and cleaning of semiconductor surfaces, but they also have an obvious appeal to analysts and those concerned with the preparation of very pure materials. In the past 5 years the company has been engaged in a major effort to make the United Kingdom less dependent on imported biochemicals. Apart from producing many materials formerly available only from the United States, the Biochemical Department has made its own contribution to the range of biochomicals available commercially. Examples include $(a)$ a B.D.H. preparation for the world market of the reagent dansyl chloride and a series of dansyl derivatives of amino-acids which are important in protein research; (b) the commercial production of high quality $\varepsilon-(2: 4$ dinitrophenyl)-L-lysine hydrochloride which is important in determining lysine in foodstuffs, especially in milk. It has been important to lipid chemists in Britain that the company has provided reasonably priced mothyl esters of very pure higher fatty acids. B.D.H. is playing a large part in the supply of reagents to hospital laboratories. The bacteriologist has benefited from a mucous digestant, $N$-acetyl-L-cysteine; some tetrazolium salts of exceptional quality are speeding the work of the histologist and cytologist (also of those concerned with seed viability testing). Special attention is being paid to the demands of automatic analysis in clinical laboratories by providing ready-made solutions and convenient forms of other reagents.

\section{The Cape Asbestos Company, Ltd.}

The Cape Asbestos Company, Ltd., is the parent company of the Cape Asbestos Group, an international organization with widespread industrial ramifications. The Mines Division includes Cape Asbestos South Africa (Pty.), Ltd., the South African parent company, and affiliated firms, operating amosite mines at Penge, Weltevreden, Kromellenboog and Malipsdrift, blue asbestos mines at Koegas, Westerberg, Pomfret and Warrendale; also the London-based Cape Asbestos Fibres, Ltd., concerned with the promotion, sale and distribution of raw and processed asbestos fibres. The Insulation Division is concerned with various proprietary insulating materials, for example, rockwool, asbestos yarn and cloth, asbestos millboard, rope lagging, packings and jointings, plastic finishing and insulating compositions and asbestos reinforced plastic sheeting, insulation; this Division operates in London, Liverpool, Dublin, and at Benoni, Transvaal. The Board Products Division incorporates Cape Building Products, Ltd., Uxbridge, makers of 'Asbestolux' board and the well-known Uxbridge Flint Bricks, Harefield Lime Company, producing lime for brick manufacture, and Marinite, Ltd., London and Glasgow, who make the popular 'Marinite' asbestos sheet.

Companies operating in the Engineering Division include Small and Parkes, Ltd., Manchester, concerned with brake and clutch linings, disk brake friction pads for automotive and industrial applications, fanbelts, engineering plastics; others trading elsewhere in Britain, in Brussels, and at Benoni South, Transvaal, are concerned with general garage equipment. That at Fareham, Hampshire, is concerned with water jet propulsion units for pleasure and commercial craft. There is a separate Overseas Division, based in Chicago, Toronto and Turin, which handles the sale of various asbestos products. Associated companies, concerned mostly with packings, jointing and insulating products, are located in Argentina, Canada, France, and elsewhere. This information about the activities of the Group is chronicled in the house journal, Cape Magazine (14, No. 3; Autumn 1965. 114 Park Street, London, W.1). Although most of this periodical is concerned with internal staff matters, from United Kingdom and overseas centres, a few short articles are of wider interest, one dealing particularly with the new rules (1965) governing structural fire pro- 